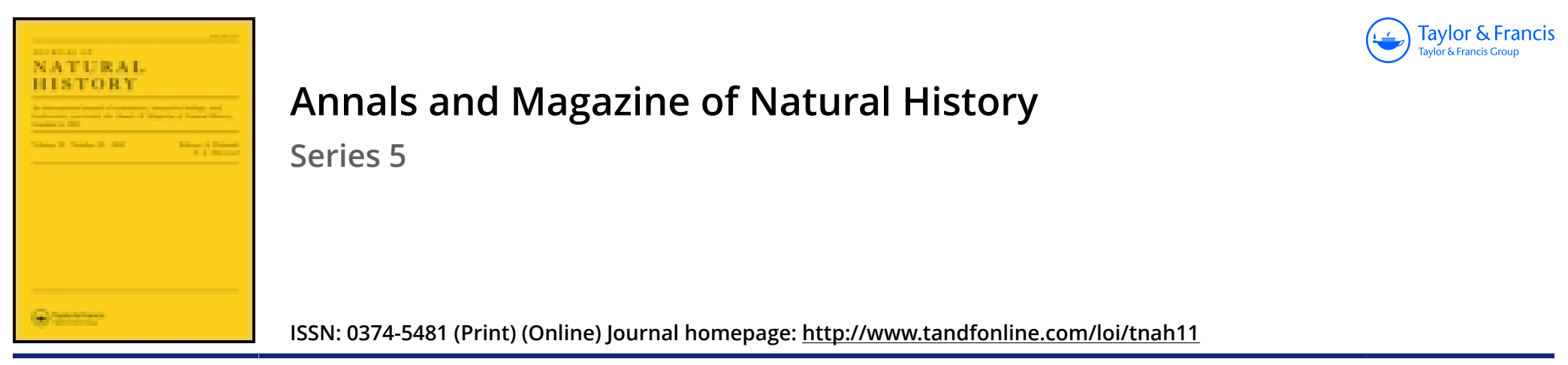

\title{
XXIX.-On a collection of Lepidoptera made at Manipur and on the borders of Assam by Dr. George Watt
}

\section{Arthur G. Butler F.L.S. F.Z.S.}

To cite this article: Arthur G. Butler F.L.S. F.Z.S. (1885) XXIX.-On a collection of Lepidoptera made at Manipur and on the borders of Assam by Dr. George Watt, Annals and Magazine of Natural History, 16:94, 298-310, DOI: 10.1080/00222938509459884

To link to this article: http://dx.doi.org/10.1080/00222938509459884

曲 Published online: 09 Oct 2009.

Submit your article to this journal $\pi$

Џll Article views: 4

Q View related articles $\sqsubset$ 
35, 36.-A number of specimens of Hyla pulchella obtained by Dr. v. Ihering have convinced me that the difference in the dentition upon which $H$. Vauterii has been separated from that species is merely individual, and I therefore unite the two.

37.-The description of Paludicola ranina agrees with my $P$. gracilis, published in January 1883, but which Prof. Cope appears to have overlooked.

40. - The occurrence so far south of Pseudis paradoxa would be surprising; but as the list does not mention P. mantidactyla, which is very abundant in the province, I cannot help suggesting that an error in the determination has been made.

In conclusion, I think not one of the new species described in Prof. Cope's paper deserves to stand, with the exception, perhaps, of Liophis fuscus. His list contains only seven species not recorded in mine; of these, four have already been mentioned from Rio Grande do Sul by Hensel, viz. :-Drymobius pantherinus, Philodryas Olfersii, Xenodon rhabdocephalus, and $X$. Neovidii. Tachymenis hypoconia, Leptognathus Catesbyi, and Oxyrhopus plumbeus are apparently recorded from that province for the first time.

XXIX.-On a Collection of Lepidoptera made at Manipur and on the Borders of Assam by Dr. George Watt. By ARTHUR G. ButLer, F.L.S., F.Z.S., \&c.

[Plate VIII.]

In the year 1880 I had the pleasure of bringing before the Zoological Society an account of a collection made by Dr. Watt (Professor of Botany in the Calcutta University) principally in North-west India, and containing eight new species. Shortly after the publication of this paper Dr. Watt returned to India with the intention of starting immediately to explore Manipur; I, however, heard nothing more of him until the autumn of 1883, when he forwarded a large box of Lepidoptera in envelopes, and amongst them a smaller box of mounted specimens of all the species taken in Manipur, the remainder of the species having been obtained "on the N.E. frontier of India bordering on Assam." 
Thirty-five species were obtained at or on the approach to Manipur, of which the following is a list :-

Caduga melanens, $C r$.

Ypthima nareda, Koll.

Thaumantis diores,. $\mathrm{Dbl}$.

- camadeva, Westw.

Moduza procris, $\mathrm{Cr}$.

Athyma cama, $M$.

Rahinda hordonia, St.

Euthalia teuta, $D b l$.

Symphædra dirtea, $F$.

Eulepis samatha, $M$.

Prothoë regalis, Btl.

Euripus halitherses, Westw.

Myrina etolus, $F$.

Dercas Verhuellii, Hoev.

Ixias evippe, $D r$.

Hebomoia glaucippe, $L$.

Prioneris thestylis, $G r$.

Appias galba, Wall.
Appias eleonora, $B$.

$\underline{\text { Pacans, } B t l \text {. }}$.

Hiposcritia lalage, $G r$.

- pseudolalage, $\boldsymbol{M}$.

- argyridina, Btl.

- shiva, Swin.

- mahana, $\boldsymbol{M}$.

Huphina nama, $\boldsymbol{M}$.

Ganoris gliciria, $C r$.

Papilio antiphates, $C r$.

doson, Feld.

- acheron, $M$.

- sarpedon, $L$.

- agamemnon, $L$.

- xenocles, $G r$.

Protoparce orientalis, Btl.

Amesia aliris, $D b l$.

There is therefore nothing in the Lepidoptera received in the present collection, with the exception of the Malayan genus Prothöe and the new species of Hiposcritia, which might not have been obtained at Assam; even the presence of Prothö̈ in Assam would not astonish me, since not a few Malayan types range quite as far northwards, even the same species being caught in Assam and Borneo ; the present series from the vicinity of Assam fully bears out this fact.

Dr. Watt fully expected to remain at Manipur for three years, but was most unfortunately recalled soon after his arrival there; so that the collection is doubtless by no means so complete as we could wish; still, as next to nothing is known of its fauna, every addition must needs be welcome, and, considering how little opportunity Dr. Watt had of making a collection at all, owing to numerous other occupations, the series of species sent home by him is by no means an insignificant one.

\section{Nymphalidx.}

\section{EUPLEINA.}

\section{Caduga melaneus, var.}

Pupitio melaneus, Cramer, Pap. Exot. i. pl. xxx. D (1775).

Manipur.

Only one injured example of this species was obtained. 
2. Parantica melanoides.

Parantica melanoides, Moore, P. Z. S. 1883, p. 247. n. 1.

One pair. Borders of Assam.

3. Limnas chrysippus.

Papilio chrysippus, Linnæus, Mus. Lud. Ulr. p. 263 (1764).

Males only. Near Assam.

4. Salatura genutia.

Papilio genutia, Cramer, Pap. Exot. iii. pl. cevi. C, D (1782).

Three pairs. Near Assam.

5. Tirumala septentrionalis.

Danais septentrionalis, Butler, Ent. Month. Mag. xi. p. 163 (1874).

'Three pairs. Near Assam.

6. Danisepa rhadamanthus.

Papilio rhadamanthus, Fabricius, Ent. Syst. iii. 1, p. 42. n. 127 (1793).

A male. Near Assam.

\section{Penoa alcathö̈.}

Danais alcathoë, Godart, Enc. Méth. ix. p. 178. n. 5 (1819).

ð. Near Assam.

8. Penoa deione.

Euploea deione, Westwood, Cab. Orient. Ent. pl. xxxvii. fig. 3 (1848).

A male. Near Assam.

9. Trepsichrois Van-Deventeri.

Trepsichrois Van-Deventeri, Forbes, Nat. Wand. p. 274 (1885).

A series. Near Assam.

\section{Isamia irawada.}

Euplcea irawada, Moore, Ann. \& Mag. Nat. Hist. ser. , vol. xx. p. 45 (1877).

Isamia irawada, Moore, P. Z. S. 1883, p. 311. n. 2.

One beautiful male. Near Assam. 
SATYRINE.

11. Anadebis himachala.

Mycalesis? himachala, Moore, Cat. Lep. E. I. Co. i. p. 234. n. 503 (1857).

One poor specimen. Near Assam.

\section{Lethe latiaris.}

Debis latiaris, Hewitson, Exot. Butt. iii. Debis, pl, i, fig. 4 (1862).

‥ Near Assam.

13. Lethe verma.

Satyrus verma, Kollar, in Hiigel's Kaschmir, iv. 2, p. 447, pl. xvi. figs. 1, 2 (1848).

q. Near Assam.

14. Callerebia orixa, var.

Callerebia orixa, Moore, P. Z. S. 1872, p. 555.

ס. Near Assam.

Differs from the typical male (from the Khasia Hills) in the narrower zone to the ocellus of the primaries, which is also more oval in form, the obsolete character of the ocellus on the secondaries, and the absence of the ocelli and greyer tint on the under surface of these wings : it may prove to be distinct; but as only one somewhat rubbed example was obtained, it would at present be premature to separate it.

\section{Pachama mestra, var.}

Mycalesis mestra, Hewitson, Exot. Butt. iii. Mycal. pl. i. figs. 2, 3 (1862).

o. Near Assam.

The single example obtained differs from the type in its slightly smaller ocelli, the narrower white band, and greyish instead of whitish sinuated submarginal stripe on the underside.

\section{Calysisme periboea?}

Papilio peribcen, Fabricius, Ent. Syst. iii. 1, p. 234. n. 730 (1793).

․ Near Assam.

The single example obtained is somewhat worn and shattered; it corresponds fairly well with the description by Fabricius, but may be distinct; it chiefly differs from $\dot{C}$. mamerta of Cramer in the greater width of the yellowish-white band on the under surface, the general greyish coloration, the Ann. \& Mag. N. Hist. Ser. 5. Vol. xvi. 
greater width between the two submarginal lines, the inner one of which is less strongly undulated, and the smaller and less prominent ocelli, only two on the under surface of the primaries being at all easily seen.

17. Gareris sanatana.

Mycalesis sanatana, Moore, Cat. Lep. E. I. Co. i. p. 231. n. 489 (1857).

ð. Near Assam.

18. Ypthima nareda.

Satyrus nareda, Kollar, in Hiigel's Kaschmir, iv, 2, p. 451 (1848).

Two pairs. Manipur, Nov. 15th.

The specimens are unfortunately much shattered.

19. Ypthima methora.

Ypthima methora, Hewitson, Trans. Ent. Soc. ser. 3, vol. ii. p. 291, pl. xviii. figs. 20, 21 (1865).

A pair. Near Assam.

\section{I'pthima ordinata?}

Ypthima ordinata, Butler, P. Z. S. 1880, p. 148. n. 5, pl. xv. fig. 3.

‥ Near Assam.

The single example obtained is a good deal worn; it agrees far more closely with $Y$. ordinata than with any other species hitherto described, especially in the size of the metallic pupils to the ocelli of the primaries and in general coloration: the ocelli on the under surface do not, however, form a perfect series, as in my type; they are a little smaller, and arranged in pairs. The type of $Y$. ordinata was from Bengal.

\section{ELYMNINA.}

21. Elymnias leucocyma.

Biblis leucocyma, Godart, Enc. Méth. ix. p. 326. n. 3 (1819).

․ Near Assam.

\section{MORPHINA.}

22. Thaumantis diores.

Thaumantis diores, Doubleday, Ann. \& Mag. Nat. Hist. ser. 1, vol. xvi. p. 234 (1845).

Three examples. Manipur.

The specimens are a little worn; two of them are males. 
23. Thaumantis camadeva.

Thaumantis camadeva, Westwood, Cab. Orient. Entom. pl. iv. (1848).

Eight beautiful specimens. Manipur.

\section{NYMPHALINE.}

\section{Argynnis Childreni.}

Argynnis Childreni, G. R. Gray, Zool. Miscell. p. 33 (1841); Lep. Ins. Nepal, p. 11, pl. xi. (1846).

Two males. Near Assam.

\section{Argynnis niphe.}

Papilio niphe, Linnæus, Syst. Nat. i. 2, p. 785 . n. 208 (1767).

A series of both sexes. Near Assam.

The specimens of this and most of the Assamese species which were obtained by Dr. Watt during his journey are in a much rubbed and generally worn condition, whereas those obtained at Manipur are carefully collected, and consequently in a very fair state of preservation.

26. Cirrochroa aoris.

Cirrochroa aoris, Doubleday and Hewitson, Gen. Diurn. Lep. pl. xxi. fig. 1 (1848).

Ђ. Near Assam.

27. Cirrochroa rotundata.

Cirrochroa rotundata, Butler, Trans. Linn. Soc., Zool. (2) i. p. 543 (1877).

Near Assam.

Fourteen more or less worn specimens were obtained.

28. Atella sinha.

Terinos sinha, Kollar, in Hügel's Kaschmir, iv. 2, p. 438 (1848).

Near Assam.

29. Cethosia biblis.

Papilio biblis, Drury, Ill. Exot. Ent. i. pl. iv. tig. 2 (1773).

ð. Near Assam.

30. Cethosia cyane.

Papitio cyane, Drury, Ill. Exot. Ent. i. pl. iv. fig. 1 (1773). б우. Near Assam. 
31. Parthenos gambrisius.

Papilio gambrisius, Fabricius, Ent. Syst. iii. 1, p. 85. n. 264 (1793).

ð. Near Assam.

32. Modusa procris.

Papilio procris, Cramer, Pap. Exot. ii. pl. cri. E, F (1779).

Manipur.

33. Athyma cama.

Athyma cama, Moore, Cat. Lep. E. 1. Co. i. p. 174, n. 357, pl. v. $a$. fig. 5 (1857).

ð. Manipur.

34. Athyma selenophora.

Limenitis selenophora, Kollar, in Hügel's Kaschmir, iv. 2, p. 426, pl. vii. figs. 1, 2 (1848).

ठ․ Near Assam.

35. Athyma zeroca.

Athyma zeroca, Moore, P. Z. S. 1872, p. 564.

o. Near Assam.

36. Athyma mahesa.

Athyma mahesa, Moore, Cat. Lep. E. I. Co. i. p. 176 . n. 360 , pl. v. a. fig. 7 (1857).

o. Near Assam.

One somewhat melanized specimen, evidently belonging to this species.

\section{Athyma inarina.}

Athyma inara, Moore (nec Doubl.), P. Z. S. 1858, pl. 50. fig. 6.

A comparison of the two figures representing $A$. inara will at once decide their specific distinctness, the commoner species figured by Moore having the orange and white bands considerably narrower than in the typical form represented in the ' Genera of Diurnal Lepidoptera.'

o. Near Assam.

\section{Athyma leucothoë.}

Papilio leucothö̈, Linnæus, Mus, Lud. Ulr. p. 292 (1764).

ঠ. Near Assam. 


$$
\text { 39. Neptis, sp. n. }
$$

Allied to $N$. intermedia, but too much damaged to be fit for description, especially from a unique example.

Near Assam.

40. Neptis mananda.

Neptis mananda, Moore, P. Z. S. 1877, p. 586, pl. lviii. fig. 4.

Near Assam.

$$
\text { 41. Neptis astola. }
$$

Neptis astola, Moore, P. Z. S. 1872, p. 560.

Near Assam.

42. Neptis Swinhoei.

Neptis Swinhoei, Butler, P. Z. S. 1883, p. 145. n். 4.

Near Assam.

43. Rahinda hordonia.

Papizio hordonia, Stoll, Suppl. Cramer, pl. xxxiii. figs. 4, $4 d$ (1790).

"Ascent to Manipur from Cachar, Dec. 1881."

\section{Euthalia teuta.}

Adolias teuta, Doubleday and Hewitson, Gen. Diurn. Lep. pl. xliv. fig. 2 (1850).

ð. "Barak river, on ascent to Manipur, Dec. 1881."

45. Symphodra cyanipardus.

Symphadra cyanipardus, Butler, P. Z. S. 1868, p. 613. n. 4.

ð. Near Assam.

46. Symphredra dirtea.

Papilio dirtea, Fabricius, Ent. Syst. iii. 1, p. 59. n. 184 (1793).

$\delta$. Manipur.

47. Apatura chevana.

Athyma chevana, Moore, P. Z. S. 1865, p. 763, pl. xli. fig. 1.

ð. Near Assam. 


\section{Eulepis samatha.}

Charaxes samatha, Moore, P. Z. S. 1878, p. 831.

Eulepis samatha, Moore, Jep. Ceylon, i. p. 29 , pl. xiv. figs. $2 a, 2 b$ (1880).

Mylang River, Dec. 1881.

49. Haridra agna.

Charaxes agna, Moore, P. Z. S. 1878, p. 832.

3. Near Assam.

50. Haridra hindia.

Charaxes hindia, Butler, Lep. Exot. p. 99, pl. xxxvii. fig. 5 (1872).

ð. Near Assam.

51. Haridra khimalara.

Charaxes khimalara, Butler, Lep. Exot. p. 97, pl. xxxvii. fig. 1 (1872).

б. Near Assam.

52. Haridra dolon.

Charaxes dolon, Westwood, Cab. Orient. Ent. pl. xxvii. figs. 2, 3 (1848).

Near Assam.

53. Prothoë regalis. (PI. VIII. fig. 1.)

Prothoë regalis, Butler, Ann. \& Mag. Nat. Hist. vol, xvi. pp. 53, 54 (JuIy 1885).

Basal third of wings and body above olive-green: primaries crossed obliquely from the middle of costa to the third fourth of the inner margin by a broad silvery-blue belt, the external edge of which is irregularly notched and only separated by a blackish submarginal streak from three large spots of the same colour upon the centre of the external border; veins slenderly black, terminating in blackish spots, two of which are placed between the above-mentioned blue spots; two white spots followed by a blackish streak upon the costal part of the blue belt; a large triangular black spot closing the discoidal cell; apical area chocolate-brown; three subapical spots, the upper two large, placed obliquely, bluish, with white centres, the third submarginal, bluish, small: secondaries with the centre of the wing blue-black; apical area and external border chocolate-brown; two linear apical blue dashes and a blue line along the base of the fringe. 
Under surface of primaries whity brown, slightly tinted with greenish towards the base and with lilacine along the external border; markings very similar to those of $P$. Francki, but the outline-spots on the discoidal area filled in with dark olivaceous, with no trace of an oblique white band and with all the internervular submarginal markings cruciform: secondaries with the basal half as in P. Francki, excepting that the discoidal spots are filled in with dark olivaceous; external half considerably darker, its inner half greyish olivaceous, enclosing a series of oblong internervular black patches, which are sinuated in front and bounded by reddish crescentic borders; immediately beyond these reddish crescents is a submarginal series of eight unequal black-edged bronzegreen spots, with brighter green borders; these spots are irrorated and more or less suffused with blackish; from apex to second median branch is a series of gradually increasing marginal black spots, edged externally with pink, the last two crossed by a red stripe; a large bright olive-green semicircular spot, with black inner border and bluish-white outer border at outer extremity of first median interspace, and a large black spot, crossed by a red $\boldsymbol{\Lambda}$-shaped marking, and bordered along its infero-exterior border with grey, at extremity of interno-median area; a triangular black and red spot at extremity of abdominal fold. Expanse of wings 80 millim.

Manipur.

On the upper surface this beautiful species may be at once distinguished from P. Francki of Java by the broader, nore irregular, and greyer blue belt across the primaries, the absence of a white band on this belt, the blue marginal spots, and the blue or bluish subapical spots; the secondaries also have blue instead of white marginal dashes at apex, and the external border and apical area are chocolate-brown instead of purplish brown.

\section{Eurhinia fulva.}

Rhinopalpa fulva, Felder, Wien. ent. Monatschr. iv. p. 399. n. 21 (1860).

Near Assam.

\section{Cyrestis thyodamas.}

Cyrestis thyodamas, Boisduval, in Cuv. Règne Anim. Ins. ii. pl. exxxviii. fig. 4 (1836).

Near Assam.

This species has long been confounded with the following, which, if not distinct, must surely, I think, be a seasonal form; it has probably been assumed (without examination) to be the female of $C$. thyodamas. 


\section{Cyrestis ganescha.}

Amathusia ganescha, Kollar, in Hügel's Kaschmir, iv. 2, p. 430, pl. vii. figs. 3, 4 (1848).

Near Assam.

This is a yellow insect, with most of the markings on the wings of a deeper yellow, a few only remaining black; the apical area is not smoky brownish, as in C. thyodamas. If it be a seasonal form of the preceding, one form must have been just disappearing as the other emerged from pupa, for in no other way can one account for both of them having been taken by Dr. Watt at about the same time.

\section{Euripus halitherses.}

Euripus halitherses, Westwood and Hewitson, Gen. Diurn. Lep. pl. xli. fig. 2 (1850).

o. " Ascent to Manipur from Cachar, Dec. 1881."

Only a single damaged specimen was obtained; the female (which we have received from Cachar) is the form to which Mr. Moore gave the name of Hestina isa; we have it also in both sexes from Darjiling.

\section{Junonza asterie.}

Papilio asterie, Linnseus, Syst. Nat. i. 2, p. 769. n. 133 (1767).

Near Assam.

\section{Junonia ænóne.}

Papilio œnone, Linnæus, Mus. Lud. Ulr. pp. 274, 275 (1764).

Near Assam.

\section{Junonia orithyia.}

Papilio orithyiu, Linnæus, Mus. Lud. Ulr. p. 278 (1764).

Near Assam (eighteen examples).

Under this name a number of local forms are usually associated, all of which appear to be constant. The true $J$. orithyia is a Chinese species ; it ranges into Japan and Siam, but I am doubtful whether it is identical with the Indian form or forms; it certainly appears to be distinct from the species obtained by Col. Swinhoe in Mhow and Poona, a good series of which, owing to his liberality, we possess, and all of which are decidedly paler on the under surface than the Chinese insect, and have the pale markings on the apical area of the primaries above quite white; the latter form also 
is uniformly smalter, and the blue areas upon the wings are less tinged with green. I think that in calling this local form $J$. Swinhoei I am separating as good and constant a type as that of Java, named $J$. ocyale by Hübner, that of Malacca, to which Mr. Distant has given the name of $J$. Wallacei, or that of Turkey and Arabia, recently named by Mr. Lang; those who maintain that all these forms should still be commingled under the name of $J$. orithyia are perfectly at liberty to hold that opinion-the fact of the existence of local differences still remains.

\section{Symbrenthia hippoclus.}

Papilio hippocilus, Cramer, Pap. Exot. iii. pl. cexx. O, D (1782). Near Assam.

\section{Hestina nama.}

Diadema nama, Doubleday, Ann. \& Mag. Nat. Hist. xvi. p. 232 (1845). Near Assam.

The genus to which the following species belongs has hitherto been placed in this part of the Nymphalinæ; I have, however, not the least doubt (in spite of its short thickened antennæ) that its proper place is in the Satyrinæbetween Zethera and Orinoma; the neuration of the wings is almost identical with that of the latter genus. M. Oberthür's notion that Calinaga should be placed among the Papilionidæ shows that he has not examined its structure; no Papilio has aborted front legs.

63. Calinaga brahma, sp. n.

Nearly allied to $C$. buddha, but both sexes suffused with greyish, especially in the discoidal cell of primaries, so that the bands across and at the end of the cell are blurred and indistinct; the elbowed discal series of spots more or less suffused and reduced in size, as are also the spots beyond the cell of secondaries; the extremity of the cell in these wings is partly filled in with grey; the thorax is of a more orange tint than in C. buddha. Expanse of wings, $\delta 91$ millim., \& 101 millim.

Near Assam.

Two males and a female were obtained.

\section{Ergolis merione.}

Papitio nerione, Cramer, Pap. Exot. i. pl. lxxxvi. E, F (1779).

Near Assam. 


\section{Kallime inachis.}

Paphia inachis, Boisduval, in Cuvier's Règne Anim. Ins. ii. pl. exxxix. fig. 3 (1836).

Near Assam.

\section{AORAINE.}

66. Pareba vesta.

Papilio vesta, Fabricius, Mant. Ins. ii. p. 14. n. 130 (1787).

Near Assam.

Fifteen examples were obtained, showing the usual varia. tions in colour and pattern.

\section{Erycinidæ.}

\section{Zemeros flegyas.}

Papilio flegyas, Cramer, Pap. Exot. iii. pl. cclxxx. E, F (1782).

Near Assam.

\section{Abisara fylla.}

Taxila fylla, Westwood and Hewitson, Gen. Diurn. Lep. pl. lxix. fig. 3 (1851).

Near Assam.

[To be continued.]

\section{PROCEEDINGS OF LEARNED SOCIETIES.}

GEOLOGICAL SOCIETY.

June 10, 1885.--Prof. T. G. Bonney, D.Se., LL.D., F.R.S., President, in the Chair.

The following communication was read:-

"Note on the Sternal Apparatus in Iguanodon." By J. W. Hulke, Esq., F.R.S., V.P.G.S.

The author remarked that although parts of the pectoral arch of Iguanodon had been identified in this country and in Belgium, nothing definite was known of the structure of tho stcrnum itself, and stated that a specimen in the collection of Mr. Beckles, from the Wealden of Hastings, seemed to throw some light upon this point. The specimen in question consists of an azygos bar, from near one end of which two smaller rods diverge laterally, the latter terminating 
Aru \& . Vag. Vat. Hist s. 5. Vol XVI. PL. VIII.
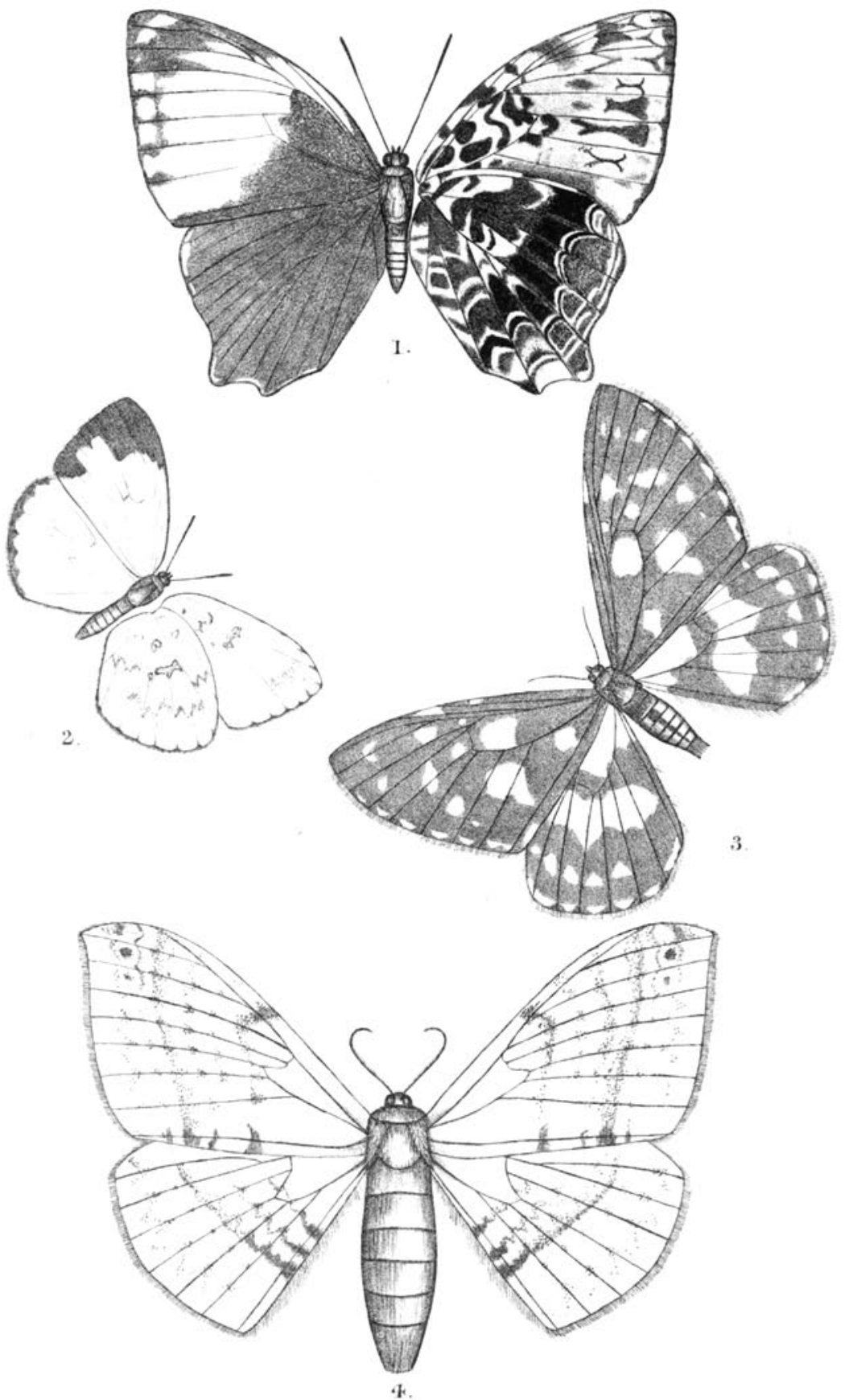

M. Horman-Fisher del et bith. 